\title{
Suggestopedic/SALT research in English Literature
}

\author{
Jennifer Wilson
}

This is a report of research carried out under the auspices of the Institute for Language Teaching, University of Stellenbosch,' at the Cape Town College of Education. The study tests and evaluates a Remedial Literature Course for English-speaking college students using Suggestopedia/SALT. The subjects in the remedial and normative groups were English-speaking students in the senior primary class. A ten-week suggestopedic/SALT English Literature Course was developed for the remedial course. Two measuring instruments were used: an English Literary Concepts Test and an Opinionnaire on attitudes towards English Literature. The validation, treatment and analysis of the data are discussed. Conclusions and recommendations follow.

Dié verslag handel oor navorsing aan die Kaapstadse Onderwyskollege onder die beskerming van die Instituut vir Taalonderrig van die Universiteit van Stellenbosch.Die ondersoek toets en evalueer ' $n$ remediërende letterkunde kursus vir Engelssprekende kollegestudente waar Suggestopedagogiek/SALT gebruik is. Die studente in die remediërende en normatiewe groepe was Engelssprekend en in die senior-primêre klas. 'n Suggestopediese/SALT Engelsletterkunde-kursus wat 10 weke sou duur, is vir die remediërende kursus ontwerp. Twee meetinstrumente is gebruik: 'n toets van Engels-literêre konsepte en ' $n$ vraelys oor houdings ten opsigte van Engels-letterkunde. Die geldigverklaring, behandeling en ontleding van data word bespreek. Gevolgtrekkings en aanbevelings volg.

\section{Statement of the problem}

The results of many first-year students in English Literature were perceived to be unsatisfactory. They responded inadequately to texts and participated very little in classroom discussion. They struggled to be "real" readers interacting purposefully with the text. Many seemed unmotivated and lacked basic understanding of how Literature works.

There are many reasons for this, not least the general approach of teachers towards examinations at the Senior Certificate level which tends to destroy any enjoyment that can be derived from reading Literature.

\footnotetext{
1 The author acknowledges the valuable part played by Dr H. L. Botha from the Institute for Language

Teaching, University of Stellenbosch, who acted as project leader.
} 
Furthermore, College students may fail a whole year if they do not pass English Literature, as they have to pass English Higher First Language every year, and English Literature forms 50 percent of the English mark.

In the light of significant work done at the same College with Second Language students using Suggestopedia/SALT and with the expertise of a qualified and experienced suggestopedic/SALT teacher on the staff, it was decided that the researcher be trained as a suggestopedic/SALT teacher in order to use Suggestopedia/SALT with mother tongue Englishspeaking students. She would then teach weak English Literature students suggestopedically.

\section{Purpose of study}

The primary purpose of this study is to design, test and evaluate a Remedial Literature Course for English-speaking College students using Suggestopedia/SALT as its method.

\section{Primary hypotheses}

It is hypothesised that :

3.1 Suggestopedia/SALT will be responsible for a meaningful improvement in the group's understanding of First Language literary concepts so that its achievements will be more comparable to that of the normative group (the rest of the second year students)

3.2 The remedial group members will achieve a higher passing score reducing the risk of failing the whole year because of English Literature, after a course in Suggestopedia/SALT

3.3 Suggestopedia/SALT will change the attitude to Literature of the remedial group meaningfully from a rather negative to a more positive one

3.4 Suggestopedia/SALT will be an effective and viable method of teaching Remedial First Language English Literature.

\section{Secondary hypotheses}

It is hypothesised that :

4.1 students will implement some of the ideas derived from the suggestopedic/SALT course in their own teaching;

4.2 students will enjoy reading, and 
4.3 students' self-concept will be enhanced through participation in the English Literature suggestopedic/SALT Course.

\section{Research design}

\subsection{Training of researcher}

The researcher was trained by Dr Ludolph Botha (on staff of the Cape Town College of Education at the time, now on staff at INTUS). Mr Louis Naudé and Prof Justus Roux of Stellenbosch University also gave guidance.

The College had designed a seminar room with one-way viewing facilities so that the researcher was also able to observe the suggestopedic/SALT cycle over ten acts. These were suggestopedic/SALT classes for students learning Afrikaans Second Language and taught by Dr Ludolph Botha.

\subsection{Target population}

The subjects in the remedial and normative groups were English-speaking second year students in the senior primary class at the Cape Town College of Education (CTCE). The majority of these students had grown up in the Cape Province. All the students involved ( $n=41)$ were studying English as a First Language.

The ages of this target population varied between 18 and 22 with an average age of 19 years and six months. Twenty nine of the 41 students were female. It is to be noted that of the 12 male students, seven were to be in the remedial group.

\subsection{Sample}

Using the pre-tests, viz. Literary Concepts Test (LCT) and Opinionnaire (OP), the 12 second year senior students weakest in English Literature were identified at the beginning of the 1986 academic year. Three of these students could not attend the suggestopedic/SALT course at the times arranged and were substituted with the next weakest students.

The 12 forming the remedial group achieved scores in the LCT pre-test ranging from 28 percent to 64 percent with an average of 52,2 percent. The remedial group consisted of five female students and seven male students.

The normative group consisted of the rest of the second year senior primary students whose scores ranged from 58 percent to 82 percent with an average of 70,8 percent.

For statistical purposes, in order to make paired analyses, a random sample of 12 students would be drawn from the normative group after the test scores had been obtained. 


\subsection{Length of instruction}

On the basis of their weakness in English, the remedial group were invited to attend an extra English Literature course voluntarily.

The programme took place during the teaching week. The students were taught English suggestopedically for four hours and 30 minutes per week for ten weeks during the second quarter of the academic year (from 8 April to 10 June 1986). As a result of public holidays and other unexpected circumstances the total number of hours amounted to 42 hours. The students also had to attend their reguiar lectures which meant another ten hours of English Literature teaching. The remedial group, therefore, had 52 hours of English Literature teaching in the period 8 April - 19 June 1986. The normative group had ten hours of Literature teaching during this period.

The remedial group were post-tested after their 42 hours but the post-testing of the normative group could not take place until they had 42 hours of 'traditional' or regular Literature teaching and had the same amount of time allocated to them as to the remedial group. The post-testing of the normative group took place on 22 October 1987. The remedial group were re-tested at that time as well.

The tests administered were the same throughout.

\subsection{Methods of instruction}

A ten week Suggestopedic/SALT English Literature Course was developed for the remedial group and they were taught suggestopedically during one and a half hour sessions on Tuesdays, Wednesdays and Fridays (four hours and 30 minutes per week) for the 42 hour course. The method was based on the theory of Suggestopedia/SALT, an applied science where the basic findings of Suggestology, as defined by Lozanov, are put into practice. The suggestopedic/SALT cycle was strictly adhered to and consisted of the following elements:

1 Each session, lasting one and a half hours, started with physical exercises, e.g. progressive relaxation.

2 Mental relaxation followed. These included:

- the "Early Pleasant Leaming Experience";

- mind-clearing exercises, concentrating on breathing while soothing music was played;

- imagining a favourite place in nature (also with soothing background music), and

- guided fantasies. 
3 Primary activations which followed were directly related to the text and included:

- choral reading from the last act;

- role-playing from the text, and

- games directly related to the text.

4 Secondary activations not directly related to the text included :

- writing own Literature, mainly poetry;

- developing own biographies;

- dramatising, and

- reading other works by writers alluded to in the text.

5 At every third session the next act of the text was introduced. A prelude was given to provide a big picture. Because this was mother-tongue and Literature, there was a need to provide a balance - freeing the students from any anxiety about the material to come, at the same time ensuring that curiosity and anticipation about the 'story' was maintained.

6 The first concert (active) followed.

7 After the first concert lights were dimmed, students stretched without talking and then relaxed to Baroque music which was part of the second concert (passive).

8 The second concert.

9 The session ended when the music was slowly phased out.

10 The students received no homework. They were only required to scan the text of the last concert just before they fell asleep in the evenings and just after they had woken up in the mornings.

\subsection{Text and text design}

The researcher, who was also the suggestopedic/SALT teacher, designed a text consisting of ten acts of approximately five to six pages each. This text took the needs and interests of the students into consideration and was written according to the criteria for a suggestopedic/ SALT text, incorporating wherever possible the suggestopedic/SALT principles and means within it. 
As the subject was English Literature, a central concern was to provide a text of literary value, one which would absorb the reader. Psychological and psychoanalytical theory of literary response indicates that response is active, creative and unique (Wilson,1984).

Tolkien compares the act of involvement in the story to one of moving from the Primary World into the storymaker's Secondary World which our minds can enter.
"Inside it, what he relates is 'true': it accords with the laws of that world. You, therefore, believe it, while you are as it were, inside.
The moment disbelief arises, the spell is broken; the magic or rather art, has failed. You are then out in the Primary World again, looking at the little abortive Secondary World from outside". (Tolkien, 1964:36)

This corresponds closely to the view that the suggestopedic/SALT text should have motivational force and have characters with whom the 'readers' can identify in order to be absorbed in the story. It also supports the view that the principles of Suggestopedia/SALT should be incorporated in an unobtrusive way to create an experience of wholeness and integrity (Kussler \& Bodenstein, 1985:13).

A short summary, however, will serve to illustrate how some of the criteria for a suitable and successful suggestopedic/SALT text were incorporated in it.

The 'story' embodies an allegorical adventure of three friends, Robyn Player (the central character), and sister and brother, Shirley and Craig Wright. They seek, essentially, to become fully integrated and creative persons. Their journey (humorously alluded to as The Pursuit of Literary Pleasures or Three Fall into Adventure Again) takes them back to their childhood delight in fantasy and they also recall the influence of a fine primary school teacher, Miss Austen, who had encouraged genuine response and recognised each child as an individual. She is the literary muse. She also represents the positive element of selfactualisation for, although now retired, Miss Austen has embarked excitedly on further studies, particularly in psycholinguistics and accelerative learning.

Craig works for a theatre company currently in production at the Baxter, so the three 'explore' the various levels of interpreting literature and at the same time rediscover the beauty of Cape Town (an opportunity for vivid sensory imagery to be incorporated appropriately). Robyn is encouraged to write and not just to concentrate on computer programming. They dream of her winning a fiction award that will take them on a literary tour of Britain. Romance between Robyn and Craig is hinted at (the students enjoyed this too) and the ending is satisfying yet sufficiently open for the reader to predict an appropriate ending. 
All students attending the regular English Literature classes studied specific texts viz. The Beadle and Cry the Beloved Country. Methods used included small group discussions with input by various groups, whole class lectures and discussions and lecturettes by students. It was expected that students be familiar with the novels when they were tackled in classroom time. Assessment at the end of the term was in the form of essays, the topics of which had been negotiated. The examination was an open-book one and was considered to be a final one with the marks allocated to a final total at year end.

The remedial group was part of this regular Literature programme (one hour per week). In addition, it attended the extra 42 hour suggestopedic/SALT Remedial Course giving the students $\mathbf{5 2}$ hours of English Literature over the period of the second term.

\subsection{Venues used}

The remedial group was taught suggestopedically in a specially equipped room with easychairs, high fidelity sound equipment, carpeted floors, plants and flowers and pictures on the walls. It was also possible to dim the lighting in this room. The room is situated at the back of the College Library and is quiet. A comfortable, relaxed atmosphere was created.

The regular English Literature lectures took place in a conventional lecture room which is similar to a conventional school classroom with classroom fixtures and furnishings.

\section{Means of data collection}

\subsection{Selection/Development of measuring instruments}

The following measuring instruments were used :

- an English Literary Concepts Test (LCT), and

- an Opinionnaire on attitude towards English Literature.

\subsubsection{Literary Concepts Test}

A multiple choice test with five possible answers was used. It was developed by the researcher and Miss M. E. Hewitt of the English Department of the CTCE.

The text focused on the literary enterprise: it examined the students' ability to recognise form (structure), the writer's intention (key elements, viz.: reality/nonreality; humour/earnestness; first person/third person; audience/adult-child), the writer's use of words (i.e. diction - literal/figurative, arrangement of words) and theme.

\subsubsection{Opinionnaire}

The Opinionnaire or attitudinal scale was based on the Likert method (Best, 1970: 
174-179) and was developed by the researcher and the English Department of the CTCE with assistance from Dr Ludolph Botha.

All the subjects completed the Opinionnaire before the Suggestopedic/SALT Remedial Course began. The remedial group completed it at the end of their course while the normative group (and remedial) group completed the Opinionnaire after 42 hours of regular Literature teaching had been completed.

There responses were possible on this Opinionnaire, viz. strongly agree (agree with in all respects) which was indicated by allocating two marks to that statement; neutral or partially agree (which was indicated by allocating one mark) and strongly disagree (do not agree with statement at all) indicated by allocating nought marks. As the numbering on the answer sheet was not in numerical order, it was difficult for the subjects to notice a pattern on the answer sheet.

\subsubsection{Times of testing}

1 The normative group completed their pre-testing on 8 April 1986 and their posttesting on 22 October 1987.

2 The remedial group completed their pre-testing on 8 April 1986 and their posttesting on 10 June 1986, immediately after their suggestopedic/SALT Remedial Course was completed.

3 Follow-up testing (using LCT test) was undertaken with the remedial group (on 22 October 1987) 10 months after post-testing, i.e. after the remedial group had been exposed to the normal traditional Literature course over 42 hours.

\section{Validation of data}

\subsection{Independent variables}

The teaching methods described above were independent variables with the remedial group taught suggestopedically and the normative group taught by means of traditional approaches. The remedial group had 42 hours of suggestopedic/SALT teaching during their 52 hours. The length of instruction described above was another independent variable.

\subsection{Intervening variables}

Intervening variables like anxiety and climatic conditions were the same for all the groups. The work load for all other subjects was the same for all students.

What is significant, however, is that the remedial group had an extra 42 hours over a ten week period in addition to their normal time-table. This short, intensive course is in strong contrast 
to the normative group receiving Literature teaching at one hour per week over a lengthy period which for purposes of research amounted to over 19 months passing before 42 hours of Literature teaching could be amassed. The method of testing and the conditions under which the testing took place were the same for both remedial and normative groups; only the times they were administered were different.

Students at the College are normally well-motivated instrumentally.This can be ascribed to the fact that all students are required to take English for three years of their diploma course and to pass it at the end of each year in order to be promoted. They are also all expected to teach English and English Literature as a school subject. Many students in the past have sought extra help and support programmes, particularly in Communication Studies.

In the case of selection of candidates for the remedial group, a further six students expressed a desire to be part of the group but only 12 could be accommodated.

It has been noted that candidates in English require a 50 percent pass mark and must pass Communication Studies. The concern then is to master this area and to hope that extra marks be gained in Literature.

Fatigue more likely played a role in the remedial group in view of the time set aside in that ten week period.

\subsection{Extraneous variables}

\subsubsection{The lecturers}

Two lecturers were responsible for the teaching of Literature to all students at the College during the time of this research. During their second year at College the students were taught by the researcher, i.e. she taught both the remedial and normative groups. In their third year at College, they were taught Literature by another lecturer.

NoSuggestopedia/SALT was used in the regular lectures and there were only a further eight hours of traditional Literature for second years in the second half of the year, taught by the researcher. Literature teaching in their third year was undertaken by another lecturer who used traditional methods and knew very little of Suggestopedia/ SALT.

\subsubsection{Testing}

As has been stated the tests were the same for all and administered under the same conditions with a neutral invigilator present.

The nature of the LCT was such that remembering detail of the test was virtually impossible. As mentioned before, it was a multiple choice test with five options; three 
passages were used (one prose and two poetry) and none of these formed part of the teaching materials used in the remedial and normative courses. The fact that the students had to apply their understanding and recognition of concepts to written data also prevented any practising or learning for the test.

With regard to the Opinionnaire, subjects were encouraged to be absolutely honest and to react as quickly and as spontaneously as possible to the statements. The subjects' co-operation and sincerity were sought.

\subsubsection{Selection bias}

A calculated group was employed. As the composition of the remedial group was calculated, bias could not play a role. The fact that the weakest group was chosen actually eliminated the possibility that the group could be given an advantage over the normative group. The normative group consisted of the rest of the second year senior primary class and only those students who missed pre- and post-testing were left out of the calculations.

\subsubsection{Contamination}

Previous knowledge of subjects could be regarded as an extraneous variable especially if the knowledge was of a positive nature which could then benefit the subjects. However, the knowledge that the researcher had of that remedial group was not positive because the weakest students had been selected to form this group. They had also been among the weakest students at the end of their first year.

It is acknowledged that the fact that the remedial group was taught by the researcher in their regular Literature classes in 1986 could be seen as an extraneous variable. It must, however, be recorded that they were part of a large class of 47 students. The methods employed in thisclass included whole class lecturing, small group discussion and centres of interest.

The researcher monitored the grouping in non-suggestopedic/SALT classes so that no one group consisted of remedial subjects only. The circumstances of a one hour lecture per week attempting to cover in-depth study of two novels, an anthology of short stories and poetry plus students rehearsing and presenting an integrated centre of interest attest to a superficial contact with the students.

The researcher did, however, bring to her teaching of Literature the same enthusiasm and commitment, be it in regular or suggestopedic/SALT classes. This factor, however subjective, must be considered a balancing one. It is also difficult for a teacher trained suggestopedically to free herself of the influence of Suggestopedia/ SALT. Consequently it might be argued that this also contributed positively to the results of the normative group. 
In 1987 all the subjects were taught by an English Literature specialist employing traditional methods only.

Three of the remedial group had been exposed to Suggestopedia/SALT in their first year. On that occasion they were studying Afrikaans as a Second Language; in this instance, English Literature First Language.

\subsubsection{Hawthorne Effect}

It is recognised that the Hawthorne Effect could play a role but only initially. It is to be emphasised that the methods employed in the regular Literature classes were recognised as innovative and appropriate.

The students had been invited to negotiate content and ways in which the regular Literature course would be evaluated. They were excited by the opportunity, for example of planning and preparing centres of interest which were evaluated by staff and the students themselves.

The researcher's findings in research for her Master of Education (1984) were implemented. In essence this called for greater emphasis on a response-centred curriculum which provided activities for whole brain learning and which acknowledged the student's individual, and often, affective response. It looked for opportunities for purposeful interaction with literary texts.

The novelty of the suggestopedic/SALT Remedial Course was therefore balanced out by the approaches used in the normative group lectures.

Because of, inter alia, the systematic orchestration of the three principles and three sets of means in Suggestopedia/SALT to establish simultaneous integration of all the brain functions in the learning process, it would be incorrect to attribute the improved results with Suggestopedia/SALT mainly, or even exclusively, to the Hawthorne Effect.

Variables, therefore, were controlled as far as possible.

\section{Treatment of data}

The researcher, under supervision of the project leader, submitted the data to the following processes:

After the pre-, post-test and follow-up scores of the Literary Concepts Test had been converted to percentages, the average of each group was determined for the pre- and posttest. Individual scores were also plotted on a graph (see figure 3) to determine whether the remedial group improved to the extent that they compared more favourably with the normative group and to ascertain whether their improved scores put them in a better position 
to pass. A randomly selected group of 12 normative subjects were drawn to represent the normative group. The pre-test scores of the remedial group and the sample of the normative group were arranged from the weakest to the highest and paired off. In other words, the weakest remedial group subject was paired off with the weakest subject of the randomly selected 12 subjects of the normative sample, the next weakest of the remedial group with the corresponding subject in the normative sample and so on. The 12 normative subjects were randomly selected; therefore, they were fully representative of the complete normative group $(n=29)$.

The pre-, post-test and follow-up scores of the Opinionnaire (OP) were compared in the following way:

The reactions of each individual subject towards the statements were totalled in two categories, viz. positive attitude toward English Literature and negative attitude towards English Literature. Each of these two categories was assessed out of 20 marks. The pre-test positive score was then subtracted from the post-test positive score, or vice versa e.g. pre-test score $=16$, post-test score $=18$, increase $=2$. Then the negative scores were subtracted, e.g. pre-test score $=10$, post-test score $=8$, decrease $=2$. The increase in positive attitude of two and the decrease in negative attitude of two were then added to indicate a general increase in positive attitude toward English Literature of four marks. These average increases were then totalled and the average was calculated. The average was verified by totalling all the scores of all the subjects in the positive and negative categories and calculating the averages of each. When the pre-test averages were compared with the post-test averages, exactly the same average difference was found with the other method of calculating the average change.

The average scores and/or increase/decrease in the pre-, post- and follow-up tests of both groups were then reflected on graphs for each of the instruments, viz. the LCT and the Opinionnaire. (See figures $1,2,3$.)

\section{An analysis and discussion of data}

To analyse the data described above, the results of the remedial group were compared with the results of the normative group.

\subsection{Changes in achievements}

The following abbreviations are used in the tables:

$\begin{array}{ll}\text { REM } & =\text { Remedial Group } \\ \text { NORM } & =\text { Normative Group } \\ \text { N } & =\text { Number } \\ \text { LCT } & =\text { Literary Concepts Test }\end{array}$




$\begin{array}{ll}\text { Op } & =\text { Opinionnaire } \\ \text { Pos Att } & =\text { Positive Attitude } \\ \text { Neg Att } & =\text { Negative Attitude } \\ \text { Pre } & =\text { Pre-test } \\ \text { Post } & =\text { Post-test } \\ \text { Diff } & =\text { Difference } \\ \text { No of Hours } & =\text { Number of hours English } \\ & \text { Literature teaching received at } \\ & \text { College } \\ X \% & =\text { Average percentage }\end{array}$

\section{TABLE 1}

AVERAGE PERCENTAGES OF PRE- AND POST-TESTS OF THE REMEDIAL GROUP IN THE LITERARY CONCEPTS TEST AND THE OPINIONNAIRE WHICH REFLECT POSITIVE ATTITUDE TOWARDS ENGLISH LITERATURE $(\mathbf{N}=12)$

\begin{tabular}{llll}
\hline VARIANTS & PRE & POST & DIFF \\
\hline LCT X \% & 52,2 & 65,7 & 13,5 \\
Op X \% & 32,1 & 57,9 & 25,8 \\
\hline
\end{tabular}

TABLE 2

AVERAGE PERCENTAGES OF PRE- AND POST-TESTS OF THE NORMATIVE GROUP IN THE LITERARY CONCEPTS TESTS AND OPINIONNAIRE WHICH REFLECT POSITIVE ATTITUDE TOWARDS ENGLISH LITERA-

TURE $(\mathbf{N}=29)$

\begin{tabular}{llll}
\hline VARIANT & PRE & POST & DIFF \\
\hline LCT X \% & 70,8 & 71,3 & 0,5 \\
Op X \% & 36,2 & 32,6 & $-3,6$ \\
\hline
\end{tabular}




\section{TABLE 3}

AVERAGE PERCENTAGES OF PRE- AND FOLLOW-UP TESTS OF THE REMEDIAL GROUP IN THE LITERARY CONCEPTS TESTS AND THE OPINIONNAIRE WHICH REFLECT ATTITUDE TOWARDS ENGLISH LITERATURE AFTER 10 MONTHS OF REGULAR LITERATURE TEACHING AND SUGGESTOPEDIC/SALT REMEDIAL COURSE $(\mathrm{N}=12)$

\begin{tabular}{llll}
\hline VARIENT & PRE & FOLLOW-UP & DIFF \\
\hline LCT X \% & 52,2 & 67,0 & 14,8 \\
Op X \% & 32,1 & 43,7 & 11,6 \\
\hline
\end{tabular}

TABLE 4

AVERAGE PERCENTAGES OF POST- AND FOLLOW-UP TESTS OF THE REMEDIAL GROUP IN THE LITERARY CONCEPTS TEST AND THE OPINIONNAIRE WHICH REFLECT ATTITUDE TOWARDS ENGLISH LITERATURE AFTER 10 MONTHS OF REGULAR LITERATURE TEACHING ONLY $(\mathbf{N}=12)$

\begin{tabular}{llll}
\hline VARIANTS & POST & FOLLOW-UP & DIFF \\
\hline LCT X \% & 65,7 & 67,0 & 1,3 \\
Op X \% & 57,9 & 43,7 & $-14,2$ \\
\hline
\end{tabular}

TABLE 5

AVERAGE PERCENTAGE POSITIVE CHANGES IN THE LITERARY CONCEPTS TESTS AND POSITIVE ATTITUDE TOWARDS ENGLISH LITERATURE

\begin{tabular}{llll}
\hline GROUPS & REM $(\mathbf{N}=12)$ & NORM $(\mathbf{N}=29)$ & DIFF \\
\hline LCT X \% & 13,5 & 0,5 & 13,0 \\
Op X \% & 25,8 & $-3,6$ & 29,4 \\
\hline
\end{tabular}




\section{2}

\section{Graphic representation of percentage changes}

Figures 1-3 reflect graphically the changes which seem to take place as a result of the treatment. Figure 1 reflects bar graphs indicating the percentage changes in the normative and remedial groups from pre- to post-test (and also to follow-up test for the remedial group) in the Literary Concepts Tests (LCT). Figure 2 reflects the changes of attitude towards Literature as measured with the Opinionnaire. (A follow-up of the Op given to the remedial group is also reflected in Figure 2.)

Figure 3 reflects a line graph indicating individual LCT scores of the 12 members of the remedial group in comparison to randomly selected sample of 12 of the normative group. The 12 subjects are in each case arranged according to pre-test scores from the lowest score (No 1) to the highest score (No 12).

\section{FIGURE 1}

\section{Literary Concepts Tests (LCT)}

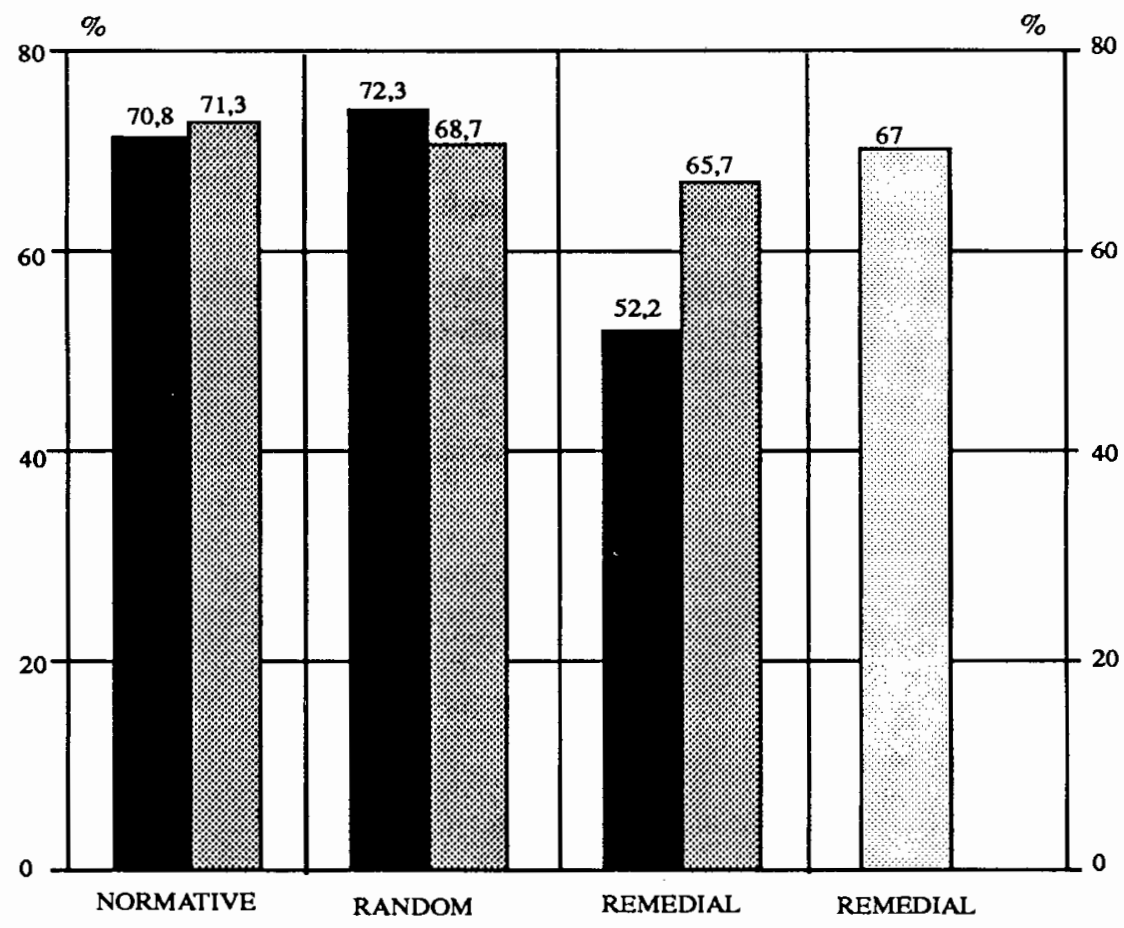

Pre-test

Post-test

Follow-up 


\section{Fig u re 2}

Opinionnaire

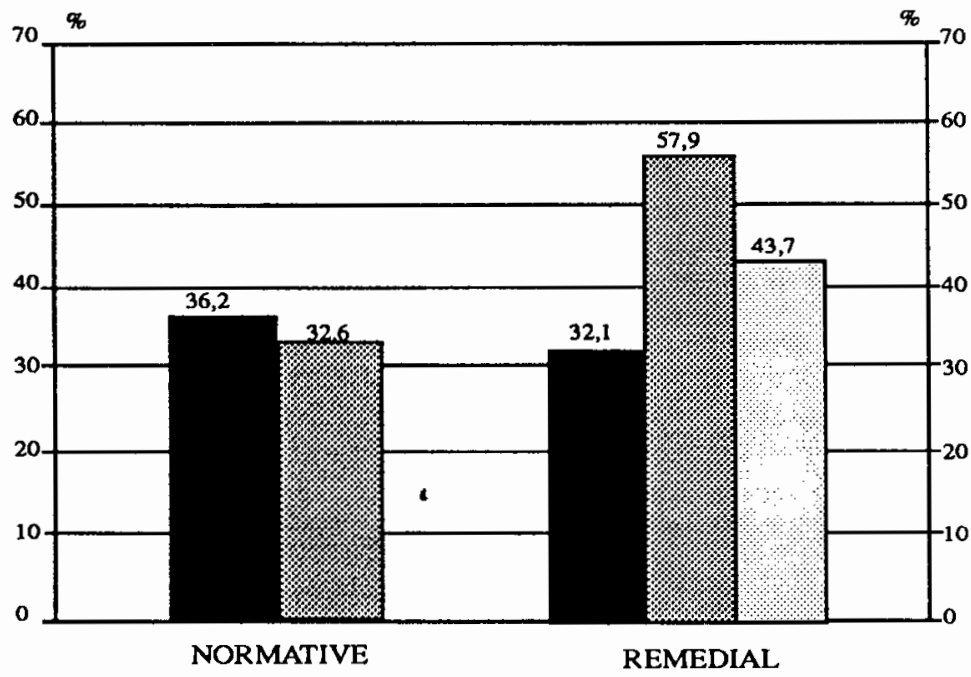

Pre-teat Pontest

In all the tests the remedial group gained meaningfully on the normative group (see Figure 1 and 2). An average difference in the LTC pre-test of $18,6 \%$ between the normative and remedial group, decreased to $5,6 \%$ in the LTC post-test. If the remedial group's follow-up average is taken, the difference becomes even more insignificant, viz. $4,3 \%$.

The remedial group's gain in positive attitude is in contrast to the normative group's decrease in attitude, i.e. an increase in negative attitude (see Figure 2). The remedial group's pre-test average on the Op is not significantly different from the normative group's pre- and post-test scores. But the remedial group's post-test average shows a marked improvement which clearly indicates that something has affected these students' attitude toward English Literature.

The next step is to investigate the meaningfulness of the changes reflected in Figure 2.

\subsection{Meaningfulness of changes in understanding literary concepts}

Figure 3 illustrates clearly that the remedial group achieved much lower results in the preLCT (Literary Concepts Test) than the randomly selected sample of 12 of the normative group. The post-test scores of the remedial group improved meaningfully and all the subjects except one, moved up to levels (percentages) which compare much more favourably with the normative group's post-test scores. The remedial group of students were all in much more favourable positions to pass English Literature well. One could, therefore, claim that the suggestopedic/SALT Remedial Course contributed to this improvement of the remedial group's literary skills. 


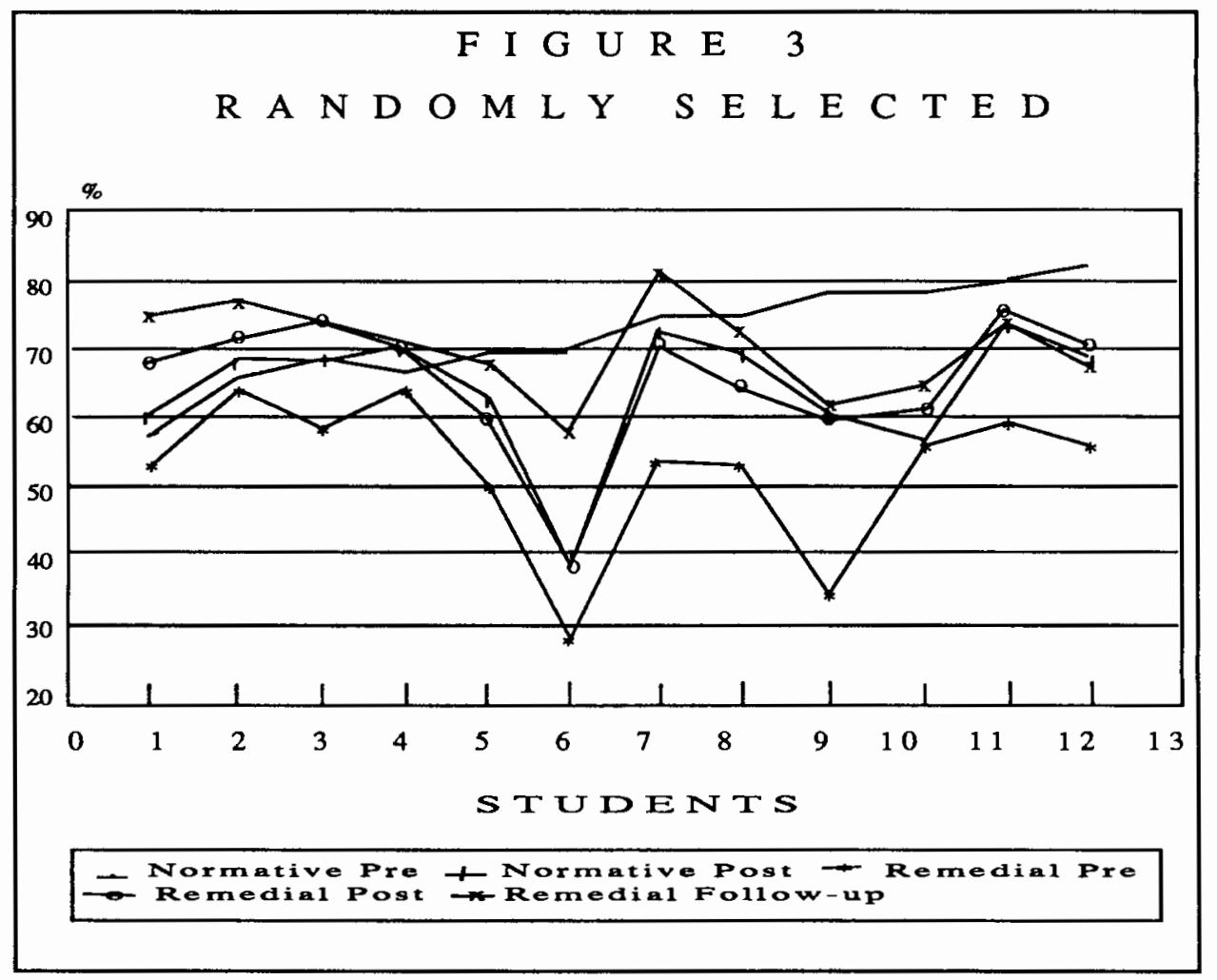

The follow-up results also reflected in Figures 1 and 3 indicate that the remedial group not only retained the initial improvement in the LTC after ten months, but actually increased the improvement to an average of $67 \%$. This could probably be ascribed to the fact that the suggestopedic/SALT course provided a firm basis in literary skills which made it possible for the remedial group to improve even more, although they received traditional Literature teaching during those ten months after the suggestopedic/SALT Remedial Course.

\subsection{Significance of changes in positive attitude toward English Literature}

The average improvement in positive attitude of $25,8 \%$ of the remedial group in contrast to the $-3,6 \%$ of the normative group is significant at the $0,1 \%$ level.

This most significant average increase may be attributed to the fact that the remedial group was taught suggestopedically. It may also indicate that the approaches adopted in the regular classes were not affecting the student's attitude towards Literature positively. The drop in positive attitude of the remedial group in the follow-up testing (ten months after the suggestopedic/SALT Remedial Course) confirms that traditional Literature teaching does not have the same effect as suggestopedic/SALT teaching on the attitude of students. Although the positive attitude decreased, it was still better than the normative group's posttest average. (See Figure 2). 
Considerable enjoyment was evident during the suggestopedic/SALT Remedial Course and this same pleasure was reflected in their informal personal reactions which were submitted in writing afterwards. The enjoyment could have contributed towards an increase in positive attitude towards English Literature. (See Section 10 for fuller discussion of the remedial group's qualitative responses.)

The remedial group particularly enjoyed the activations, especially where infantilisation was encouraged such as in role-playing and poetry writing as if they were primary school children. They valued their new identities [often literary but always English (Anglo-Saxon or Celtic) in origin].

\subsection{General discussion and conclusions drawn from tables and graphs}

From the graphs and the findings of the tests, it is clear that the remedial group

* improved in the LCT to the extent that they compare favourably with the normative group - in other words Hypothesis ONE was validated;

* were all in a much better position to pass their English Literature at the end of the academic year - they attained and even improved post-test scores - thus, Hypothesis TWO was likewise maintained, and

* became significantly more positive towards English Literature than the normative group - Hypothesis THREE was also validated.

The fact that the remedial group gained meaningfully in the LCT and in the Op could probably be attributed to the suggestopedic/SALT Remedial Course which generated a positive learning environment in order to optimise learning. It is also important to note that these results are similar to and confirm experiments done with Suggestopedia/SALT at Colleges of Education. Botha (1986: 245-310), in an experiment where Afrikaans as a Second Language was taught to college students, and Odendaal (1987: 22-23), in an experiment where English as a Second Language was taught also to college students, both reported that Suggestopedia/SALT made a significant contribution towards the improvement of the target groups' second languages.

That Suggestopedia/SALT endeavours to involve the whole brain optimally is significant, particularly when one recollects that traditional Literature teaching tends to be analytical and evaluative, seeking objectivity and is often structural and formalist in approach. The response process had been taken into account by the researcher in her Literature teaching over a number of years, recognising that reading and understanding Literature is mediated by both the reader's conscious intellect and his unconscious; that it engages emotion, memory and imagination holistically.

In spite of encouraging a response-centred approach and activities involving whole-brain 
leaming in her regular classes, the improvement was only $0,5 \%$ in comparison to the $13,5 \%$ of the remedial group.

It can, therefore, be argued that Suggestopedia/SALT accounts for this meaningful improvement in the group.

Furthermore, after 10 months from the post-test to the follow-up test, the group's retention was such that they improved from an average of $13,5 \%$ at post-testing to $14,8 \%$ at followup testing.

Not only did the gap between the normative group and the remedial group narrow, but the remedial group's improvement was retained and even extended over a period of 10 months. Both the sustained improvement and the retention could be attributed to the suggestopedic/ SALT Remedial Course which provided a sound basis as far as literary skills are concerned.

The $-3,6 \%$ decrease in positive attitude towards English Literature in the normative group is not uncommon with traditional Literature teaching and reflects the normal decline in motivation towards the end of the course. This makes the $25,8 \%$ increase in positive attitude in the remedial group all the more significant.

Elements of suggestopedic/SALT teaching that seemed to contribute to the significant improvement in the remedial group's attitude towardsEnglish literature were the following:

- the positive suggestions

- the lack of stress and anxiety cultivated in the suggestopedic/SALT situation

- the simultaneous activation of all the brain systems

- the joy generated in the suggestopedic/SALT classroom.

These benefits seemed to spill over in the testing situation allowing remedial students to perform optimally.

The follow-up test revealed that, although there was a gradual decrease in positive attitude after the post-test, there was, nevertheless, still an increase of $11,6 \%$ on the pre-test score. The decrease could possibly be attributed to the fact that the students were no longer exposed to suggestopedic/SALT Literature teaching.

The following section includes qualitative data including resposes from the remedial group.

\section{Some qualitative considerations}

The remedial group was invited to give personal impressions of the course in writing 
anonymously so that they could be as frank as they wished. All responded, some more fully than others. The responses were addressed to Heather Bridges, the researcher's fictitional name. The students signed their names and some had their real names in brackets. None was anonymous.

Most adopted the transactional mode (letter form) to comment and three included responses in the poetic mode, using poetry as the preferred form.

10.1 What follows are lists of items which summarise the impressions of each subject:

\begin{tabular}{|l|l|}
\hline & $\begin{array}{l}\text { N=12 } \\
\text { No of students }\end{array}$ \\
\hline looked forward to every class: & 1 \\
gave me confidence to tackle college asignments: & 5 \\
leamt to relax; relaxed atmosphere promoted class participation: & 9 \\
helped in practice teaching to find new, creative ways to present & \\
lessons: & 8 \\
found could communicate better: & 2 \\
more confident to teach: & 1 \\
my positive attitude helps me in all subjects: & 1 \\
liked bonding with teacher: & 1 \\
value warmth, comfort, non-threatening setting: & 4 \\
literature became more enjoyable, read more: & 7 \\
enjoyed role-playing, false identities: & 7 \\
enjoyed dreamy music, unity of group, story, games, singing & \\
songs: & 2 \\
found myself listening better: & 1 \\
sure will do better in English Literature: & 1 \\
learnt to write literature: & 1 \\
learnt to express my feelings and viewpoints - they had been & \\
suppressed before, I am a much happier person, less inhibited: & 3 \\
helped to get rid of tension and headaches: & 1 \\
free of fear of failure: & 2 \\
sometimes tiring: & 1 \\
mistakes were allowed: & 1 \\
remember better and longer: & 1 \\
new identity helped to shed inhibitions: & 4 \\
\hline
\end{tabular}

The following response, submitted in January 1987, seven months after the course, is transposed in full: 


\section{Dear Heather}

I would like to begin by apologising for taking so long to write. One of the reasons it's taken me so long is because my gains due to Suggestopedia have been very personal and too abstract to write about.

I have, since Suggestopedia, experienced changes that I could not really identify with. For example, I often get rushes of very clear images of various things when people mention certain words. I also found myself thinking along very poetic lines which I never did before. For example, a sunset was no longer a sunset, but instead it was a mixing of the day and the night in a mystical haze. A haze, that although I had seen it a hundred times, I had never really seen before. And although every sunset was the same, they were all yet very different.

I know that most of the above must seem like one big paradox, but it really is just an attempt to describe my feelings. Also due to Suggestopedia, I found that writing my feelings down helped me put a lot of things in perspective.

I know that my poetry would not win me any prizes but to me it is very special and personal. Here is one that I wrote towards the end of last year when I was thinking about studying hard and really trying to do well. I thought for a long time before writing this poem about what I had learnt and if I had learnt enough and eventually I asked myself the question - what is learning? And because Suggestopedia had encouraged me to write I decided to put my thoughts on paper.

\section{LEARNING}

As my cup fills

And the white bottom slowly disappears

I feel the warmth of what is to come

And the steam of learning becomes apparent.

As the steam now begins to rise

bringing a new sensation to the brim of my cup,

I anticipate everything, yet nothing

because who am I to want to know everything?

If I did know everything, would I be aware of it?

For how will I know if my cup is full

or if the pot is empty?

And how will I know when to seek a new pot? 
How will I know if the taste of knowing is really as sweet as I imagine it to be

And how will I know if the comforting warmth of achievement makes everything worthwhile?

The steam hovers invitingly over my now black-filled cup.

As I accept this invitation all my questions are answered.

But as I put my cup down after drinking

I realize with wonder

That the white colour of the bottom of my cup has never returned

And that the pourer has never stopped pouring And also that my thirst has not been quenched But instead it has become more desperate.

I know this poem is like a bucket of thoughts but as I said before, it clarifies my thinking.

Suggestopedia has helped me to be a better teacher, more sensitive to children, allowing them to be individual and original and me trying to make lessons fun. I encourage the children to mentally put themselves in different situations by imaging. This, I think helps, particularly in History and Geography and, of course, reading literature.

Lastly, I would like to say that Suggestopedia has given me a very positive attitude towards life. For example, I have done karate for a number of years and taking part in competitions has always been a nerve-racking experience. The nerves are, however, still there but they are now a whole lot more positive than before. I feel that I can safely say that due to Suggestopedia my performances in karate have improved enormously. (In a recent competition I came 3rd)

Once again I would like to apologize for taking so long to write but I write with belief and sincerity.

Love

XXXXXX

10.2 A questionnaire was completed in April 1988, almost two years after participating in the suggestopedic/SALT Remedial Course. There were 11 responses (one student had left the College at the end of 1987).

The answers are summarised as follows: 
1 What do you remember most of the course?

- warm relaxed atmosphere

- relaxing music

- new identities (which were fun, gave confidence)

- enjoyment, fun

- unity, intimacy within group

- the script - enjoyed story

- writing own poetry

- feeling refreshed afterwards

- freedom from sense of failure
9 students

8

7

7

4

4

3

2

1

2 Did the course have any value to you? Specify.

2.1 Improved attitude to English Literature 6

- desire to broaden Literature background 1

- Literature is to be enjoyed 2

- gained deeper insights into Literature 1

- made me less afraid of Literature and exams 2

2.2 Understand Literature better

- learnt how to read with insight 1

- gained strategies for understanding genre 2

- understand figures of speech now

2.3 Helped me as a teacher

- use techniques in classroom 
music

relaxation

dramatisation

games

poetry methods

imaging

brainstorming

mind-mapping

- to teach spelling with music and imaging

- to be more creative

- to create a fun, failure-free environment

- to be more aware of children's possibilities and needs

- to communicate more effectively

- to recognise that learning can be wonderful 1

- to be confident in the classroom 3

2.4 Helped me as a person $\quad 11$

- much happier, as a whole 1

- to relax more 3

- to be sensitive to other people 1

- given me confidence $\quad 4$

- more sure of myself 1

- to get rid of tension headaches (still exercises) 1 
- to communicate better with others

- I acknowledged a weakness and achieved success

- to think clearly and calmly whatever the situation

2.5 Helped me as a student

- I passed English! (And all subjects!)

- more positive attitude to other subjects possibly could do them

- to use relaxation exercises before studying/ after intense concentration in lectures

- recognising that 1 have capabilities

- to interact in group activities

- to approach hard work purposefully

\subsection{Discussion and conclusions drawn from the responses}

It is clear from an analysis of their responses that the remedial subjects found the suggestopedic/SALT course an enriching and invaluable learning experience.

The following aspects emerge clearly in both their early responses and their reflective ones two years later.

1 Their memories of the course were all positive. The features that most students mention in both the written response just after the course and after the follow-up test eight months later are particularly:

* the relaxed atmosphere which helped them to relax

* the suggestopedic/SALT techniques: the role playing, false identities, unity of the group, the relaxing music, the games.

2 Student teachers at Colleges of Education see as priority the need to become competent teachers. The remedial group claim that Suggestopedia/SALT had helped them in this direction on the personal, academic and professional levels. 
All involved in teacher-training would agree that Colleges of Education have two important functions: provide the prospective teachers with the skills, knowledge and intellectual resources necessary for functioning in the classroom, and to initiate them into the role of 'teachers'. This socialisation involves the development of motivation to become a good teacher and the development of a healthy selfconcept.

Another look at their responses, in terms of the above statement, will reveal that the skills of the remedial group improved in the following areas:

- the ability to communicate with others, mainly speaking and listening

- writing skills

- group interaction (this also aided in the socialisation process)

- thinking skills

- personal management/life skills.

All these could be practised and experienced in a loving, stress-free and uncritical environment. They claimed that they gained knowledge of how Literature works (the test results unequivocally support this). Some read more Literature and wrote more as a result of Suggestopedia/SALT thereby extending and enriching their knowledge of English Literature both cognitively and emotionally.

More importantly, all of them as student teachers welcomed gaining knowledge of techniques and ideas that they could implement successfully in their teaching, not only of English but across the curriculum. They were able to apply methods and strategies that made their teaching more creative and were in keeping with sound leaming theory. These, too, they had experienced and practised in the suggestopedic/SALT situation and they recognised their viability and validity.

This leads to consideration of the second key function of teacher-training: to develop in the student teacher a healthy self-concept. Effective teaching is a function of a healthy selfconcept and research indicates that student teachers who possess low self-esteem are at risk in the intense personal atmosphere of the classroom.

Hence learning about self and others and developing as a whole person are as important as academic knowledge in a college curriculum.

Clearly, from the responses of the remedial group, Suggestopedia/SALT has been of inestimable importance and value to them in this area. 
Subjects referred to

- gains in confidence that helped them on both a personal and a professional level;

- self-acceptance and acceptance of others;

- freedom from anxiety;

- feeling more sure of themselves, and

- ability to cope with life.

A number had emotional and social problems that were evidenced in comments such as "feelings repressed" and "having pressures" and "being shy". They claimed that Suggestopedia/SALT had helped them overcome these. They found ways of releasing tension, coping more adequately and developing a better self-image.

Being a fully integrated person relating to other people is an ideal in teaching if education is about benefiting the whole person. Suggestopedia/SALT has a vital role to play in this area.

\section{Conclusions and recommendations}

\subsection{Conclusions}

Suggestopedia/SALT seems a viable method to use for remedial English Literature (First Language) students at a College of Education. The students seemed to have benefited meaningfully from the course reported in this study.

Difficulties that may have to be overcome include timetabling and venue. If colleges are to modularise as the Cape Town College of Education is tending to do, the former may be overcome; the latter will depend on whether the courses are to be for small remedial groups (the venue used by the researcher comfortably accommodates up to 14 students) or be implemented to whole classes.

From both a quantitative and qualitative point of view the results of the remedial group were most encouraging.

As an English Literature specialist and teacher-trainer, the researcher sees important implications in the test results of the normative group. The teaching methods employed for the normative group were seen to be varied and innovative and appropriate to the needs of the students. The test results of the normative group, however, do not reflect this. Add to this, the quantitative and qualitative results of the remedial group and it becomes manifestly 
evident that an English Literature course using Suggestopedia/SALT should be made possible for all students.

English Literature through Suggestopedia/SALT provides an answer to the on-going question of why teachers teach Literature and how it might best be done.

The school of thinking which views Literature as 'a living tradition' can be accommodated in Suggestopedia/SALT. It is also able to accommodate more current views of literature in the curriculum.

The remedial group had the opportunity of being writers and story-tellers. In other words, they were able to participate actively in the dynamic experience of what literature is, by consciously experimenting with their own writing or 'storying'.

Suggestopedia/SALT with mother-tongue speakers is able effectively to integrate the necessary continuities between life and literature (whether it be with a small 'I' or a capital 'L'), between reading and writing, between listening and speaking and between learning to read and becoming better at it and studying literature.

The kinds of awareness gained by the remedial group helped them to understand the nature of Literature. With the methods they gained for their own teaching and the development of a healthy self-image they, in turn, will have the confidence to create a classroom environment in which their pupils will find Literature something they can write and read and understand and enjoy.

The hypotheses are re-stated in order to ascertain their confirmation:

1 Suggestopedia/SALT will be responsible for a meaningful improvement in the remedial group's understanding of First Language literary concepts and the remedial group's achievements will be more comparable to that of the normative group. In view of the findings it can be concluded that this hypothesis has been confirmed.

2 After the course the remedial group members will be in a better position to achieve a higher passing score reducing the risk of failing the whole year because of English Literature. This hypothesis has also been validated in view of the improvements of the remedial group. At the end of 1986 and 1987 all these remedial group students passed their English Literature as well as their year.

3 Suggestopedia/SALT will make a meaningful change in the attitude of the remedial group to Literature from a negative to a more positive one. This hypothesis has also been confirmed. The quantitative results showed a most significant higher average percentage improvement in attitude towards English Literature in comparison with the normative group. Furthermore the qualitative results of the 
in comparison with the normative group. Furthermore the qualitative results of the remedial group supported this, adding indisputably to the confirmation of this hypothesis.

4 Suggestopedia/SALT is an effective and viable method of teaching remedial First Language English Literature. It is an approach which can be used more widely in Colleges of Education. Based on the confirmation of the above-mentioned hypotheses, it can be concluded that this hypothesis has also been confirmed.

The secondary hypotheses are also confirmed based on the confirmation of the primary hypotheses. Suggostopedia/SALT contributed positively towards the students' acquisition of skills amd knowledge that would make them competent teachers. In addition to this, it helped them develop as whole persons with healthy selfconcepts, teachers embodying within themselves the ways of enabling their pupils to realise their full human potential.

It can, therefore, be concluded that a course in English Literature for English First Language college students using Suggestopedia/SALT is a viable one.

\subsection{Recommendations}

11.2.1 In terms of this study it is recommended that the following suggestopedic/SALT courses be implemented:

- understanding literary concepts in English Literature,

- English Literature, not only for remedial students but for all students.

11.2.2 The following aspects of Suggestopedia/SALT could be researched further:

* The development and testing of English Literature courses for in-service teachers of English First Language (both primary and secondary).

* The development and testing of English Literature courses for senior primary and secondary English First Language pupils.

* Text production using specific literary genre e.g. the novel.

* Literary Theory and Suggestopedia/SALT with specific reference to text design. 
* The application of personality tests which can test empirically the develpment of self-esteem, self-image and self-confidence in student teachers through Suggestopedia/SALT.

* The therapeutic use of Suggestopedia/SALT for counselling student teachers.

* The therapeutic use of Literature in Suggestopedia/SALT for students and for pupils.

* Imaging, Imagery and the Imagination - the development of a course on Writers and Writing using Suggestopedia/SALT.

* Suggestopedia/SALT and the college curriculum.

The researcher has sought to be as objective and factual as possible. It seems, however, that it is appropriate to conclude the findings into a suggestopedic/SALT Remedial Literature Course, with a poem.

This haiku was written by one of the students whose fictitional identity was Joyce (Joyous) Ingle (English). It was written as part of her response to the course and captures the quintessence of what Suggestopedia/SALT is and what it is able to do.

The day was misty.

The sun was hidden from sight...

Thank God for the wind.

\section{Bibliography}

ALBRECHT, KARL. 1980. Brain power: Learn to improve your thinking skills. New Jersey: Prentice Hall.

BRANCROFT, W. JANE. 1985. Accelerated Learning Techniques for the Foreign Language Classroom. Per Linguam Vol. 1 No. 2 20-24.

BEST, JOHN W. 1970. Research in education. Second Edition, New Jersey: Prentice Hall.

BETTELHEIM, BRUNO. 1976. The uses of enchantment. London: Thames and Hudson.

BLAIR, ROBERT W. 1982. Innovative approaches to language teaching. Ma.: Newbury House Publishers.

BLAIR, ROBERT W. 1985. Stories and story telling in first-level language learning: A re- 
BOTHA, H. LUDOLPH. 1986. Suggestopaedia for second language acquisition. Unpublished Doctoral Dissertation, University of Stellenbosch.

BURNS, R. 1983. Self-concept development in education. London: Holt, Rinehart \& Winston.

BUZAN, TONY. 1974. Use your head. London: Ariel Books.

DHORITY, LYNN. 1984. Acquisition through creative teaching. ACT. The artful use of suggestion in foreign language instruction. Sharon, Ma: Centre for Continuing Development.

DHORITY, LYNN. 1985. Penetrating learning barriers and the art of suggestion. Per Linguam Vol. 1 No. 2 12-19.

HAND, JAMES D. 1984. Lozanov's method for study and brain functions (Suggestopaedia). INTUS NEWS Vol. 8 No. 222.

HARDING, D. W. 1962. Psychological processes in the reading of fiction. British Journal of Aesthetics Vol. 2 No. 2 133-147.

HARDY, BARBARA. 1975. Tellers and listeners : The narrative imagination. London: The Athlone Press.

HOLLAND, NORMANN. 1975. Five readers reading. New Haven: Yale University Press.

INGLIS, FRED. 1969. The Englishness of English teaching. London: Longmans.

ISER, WOLFGANG. 1978. The act of reading: A theory of aesthetic response. Baltimore: The John Hopkins University Press.

KRASHEN, STEPHEN D. and Tracy D. Terrell. 1983. The natural approach. Language acquisition in classroom. New York: Pergamon Press.

KUSSLER, RAINER and R. Bodenstein. 1985. Suggestopaedic texts for foreign language teaching: some literary and didactic considerations. Per Linguam Vol. 1 No. 1 11-20.

LESSER, SIMON. 1960. Fiction and the unconscious. London: Owen.

LOZANOV, GEORGI. 1978. Suggestology and outlines of Suggestopedy. Translated by Marjorie Hall-Pozharlieva and Krassimira Pashmakova. New York: Gordon and Breach. 
MEEK, M.; A. WARLOW and G. Barton. 1977. The cool web. London: The Bodley Head.

MILLER, JANE. (Editor). 1984. Eccentric propositions. Essays on literature and the curriculum. London: Routledge and Kegan Paul.

MOFFETT, JAMES. 1968. Teaching the universe of discourse. Boston: Houghton Mifflin.

NAUDE, L. B. and J. J. du Preez. 1985. Die neuropsigologiese basis van die Suggestopedagogiek. Tydskrif vir Taalonderrig, Vol 19, No 3, 49-62.

ODENDAAL, M. S. 1987. Raising achievement levels by means of Suggestopedia. Per Linguam. Vol 3, No 2, 22-30.

PRICHARD, ALLYN and J. Taylor. 1980. Accelerated learning: The use of suggestion in the classroom. Novato, Ca: Academic Therapy Publications.

PURVES, ALAN. (Ed.). 1972. How porcupines make love - notes on a responsecentered curriculum. Lexington, Ma.: Xerox College Publishing.

ROSENBLATT, LOUISE. 1968. Literature as exploration. London: Heinemann Educational.

RUSSEL, PETER. 1979. The brain book. New York: E. P. Dutton Inc.

SINATRA, R. and J. Stahl-Gemake. 1983. Using the right brain in the language arts. Springfield, Illinois: Charles C. Thomas Publishers.

STEINLEY, GARY. 1983. Left brain/right brain: More of the same? Language Arts Vol. 60 No. 4 459-462.

TOLKIEN, J. R. R. 1964. Tree and leaf. London: Allen and Unwin.

WATZLAWICK, PAUL. 1978. The language of change: Elements of therapeutic communication. New York: Basic Books.

WIDDOWSON, H. G. 1978. Teaching language as communication. Oxford: Oxford University Press.

WILSON, J. S. 1984. Response to fiction: Eleven year olds as active readers. Unpublished M.Ed. Degree, University of Exeter.

WINNICOTT, D. W. 1971. Playing and reality. London: Tavistock.

WITKIN, ROBERT. 1976. The intelligence of feeling. London: Heinemann Educational. 